\title{
Antibacterial activity of the stem bark of Tieghemella Heckelii Pierre ex. A Chev against methicillin-resistant Staphylococcus aureus
}

\author{
B. G. Kipre ${ }^{1,2^{*}}$, N.K. Guessennd', M.W. Koné ${ }^{1,2,3}$, V. Gbonon ${ }^{1}$, J. K. Coulibaly ${ }^{1}$ and M. Dosso ${ }^{1}$
}

\begin{abstract}
Background: Tieghemella heckelii (Sapotaceae) is a medicinal plant used in Africa, particularly in Côte d'Ivoire for treating various diseases including infections. Identification of prospective antibacterial compounds from stem bark of this plant as a result of its medicinal virtue, led to screening activity against methicillin resistant bacteria.

Methods: Six extracts (hexane, chloroform, ethyl acetate, ethanol, methanol and sterile distilled water) were prepared and tested on methicillin resistant Staphylococcus aureus (MRSA) using broth microdilution method for activity assessment. From this experiment, the minimum inhibitory concentrations (MICs) and minimum bactericidal concentrations (MBCs) of the plant extracts were determined in sterile 96-well microplates in order to search for both bacteriostatic and bactericidal effects. Afterwards, data analysis was performed using GraphPad Prism5 software (One-way ANOVA and Turkey Multiple Comparison test). The results were then presented as Mean \pm SD for experiment repeated three times.

Results: Four extracts (ethyl acetate, methanol, ethanol and sterile distilled water) showed credible potency, with strong, significant, and moderate growth inhibition of the MRSA tested. The MIC values which varied from $45 \mu \mathrm{g} / \mathrm{mL}$ to $97 \mu \mathrm{g} / \mathrm{mL}$ according to microbial phenotype, resolutely established the activity of the plant extracts. Additionally, the MBC values which varied, depending on the type of bacteria strain, revealed the bacteriostatic and bactericidal effects of the active extracts against Methicillin-resistant Staphylococcus aureus.
\end{abstract}

Conclusion: The present study is a confirmation of the therapeutic potential of Tieghemella heckelii and its promising contribution to the discovery of a novel antibacterial drug pertaining to these resistant strains.

Keywords: Tieghemella heckelii, Methicillin-resistant Staphylococcus aureus, Antibacterial, Côte d'Ivoire

\section{Background}

Among the gram positive bacteria, Staphylococcus aureus plays a crucial role in community and nosocomial infections. To fight against these bacteria, the beta-lactams therapeutic class is mostly used in human medicine [1]. The molecular structure of these compounds could be described by a beta-lactam ring attached to variable side chains, and cycles. In fact, the pharmacokinetics, along

\footnotetext{
*Correspondence: bgkipre070@gmail.com; bkgp63@missouri.edu ${ }^{1}$ Institut Pasteur Côte d'Ivoire, Département de Bactériologie/Virologie, Centre National de Reference Antibiotiques, 3 Avenue de I'Université Cocody, B.P 490, Abidjan 01, Côte d'Ivoire

2Université Nangui Abrogoua Côte d'Ivoire, B.P 801, Abidjan 01, Côte d'Ivoire Full list of author information is available at the end of the article
}

with the antibacterial activity of each antibiotic of this group depend upon the structure of the attached side chains and cycle. Unfortunately, development of several bacteria-resistance mechanisms has caused inactivation of available current antibiotics. Consequently, community settings are endangered, for the pharmaceutical industry holds as at now, few new antibiotics to offer.

The emergence or re-emergence of bacteria-resistance has therefore become a global health concern, and public health menace in Sub-Saharan Africa, especially in Côte d'Ivoire, where methicillin resistance prevalence rate was around $34.5 \%$ in 2014 [2]. On the contrary, a great number of resistant bacteria strains were identified as seriously 
challenging current antimicrobial drugs [3]. In order to address this issue, natural products are solicited to play an incredible role, as an alternative to eradicate the multi-drug resistance [4]. For, in Africa more than 80\% of the populations use plants as medication towards infections, and $25 \%$ of the prescriptions against infectious diseases worldwide are plant-based. In this context, early studies have investigated some plants used in folk medicine [5]. Nevertheless, records in the literature do not show data on antibacterial activity of Tieghemella heckelii (Sapotaceae) [6].

The present study, therefore aims at screening the in vitro assessment of this activity towards MRSA, as well as promoting the Ivorian national flora.

\section{Methods}

\section{Plant material}

The plant material used was the stem bark of Tieghemella heckelii Pierre ex. A Chev. (Sapotaceae). The plant species was authenticated at the herbarium of "Centre Suisse de Recherches Scientifiques en Côte d'Ivoire, Adiopodoumé (Abidjan-Côte d'Ivoire)", and registered under Voucher number 3021. The stem bark was collected within the period of September to October 2014 in the Haut Sassandra, a mid-west region in Côte d'Ivoire.

\section{Bacteria strains}

Bacteria tested and their antibiogram, were provided respectively by the strains collection bank (Bio-bank) and the National Center for Antibiotics Reference at Institut Pasteur Côte d'Ivoire. These Extended-Spectrum Beta-Lactamases (ESBLs) harboring isolates were made up of six methicillin-resistant Staphylococcus aureus (MRSA). Additionally, American Type Collection Culture (ATCC) strains were used as reference material.

\section{Methods \\ Preparation of extracts}

The stem bark was shade dried over 15 days, and powdered in a mortar. Then, the extracts were prepared by macerating successively $200 \mathrm{~g}$ of plant powder in $1 \mathrm{~L}$ of the different solvents of increasing polarity. Extraction was carried out for $48 \mathrm{~h}$ for each solvent used. After filtration successively on hydrophilic cotton and filter paper, the extracts were dried in an oven at $40{ }^{\circ} \mathrm{C}$ to yield a dense residue. Each extract sample was then transferred to a glass vial until use.

\section{Antimicrobial assays}

The different plant extracts were serially diluted from $0.048 \mathrm{mg} / \mathrm{mL}$ to $12.5 \mathrm{mg} / \mathrm{mL}$ separately in both sterile $96-$ well microplates, and test tubes using broth microdilution method [7]. Suspension $(50 \mu \mathrm{L})$ was added to each well, and potency (MICs) was evaluated [8]; that is the lowest concentration of plant extract that completely inhibited the growth of the bacterium in the well or test tube [9]. Then, the MBC values were determined by sub-culturing the samples with no visible growth in the MIC assays. For this purpose, the inoculum was diluted from $10^{-1}$ to $10^{-4}$ in test tubes, and streak-seeded with a calibrated loop $(2 \mu \mathrm{L})$ on Muller-Hinton agar. The set-up included bacterial growth controls containing the test inoculum $(50 \mu \mathrm{L})$ and the negative controls without bacterial inoculum. Extracts controls were likewise included into the set-up. The first batch of Petri dishes containing the agar were labelled $\mathrm{A}$, and incubated at $37^{\circ} \mathrm{C}$ for $24 \mathrm{~h}$. Then, after reading the MIC values, the tube content which did not show bacteria growth, was streak-seeded on Muller-Hinton agar. This second batch was labelled $\mathrm{B}$, and the MBCs were determined by comparing bacteria growth in $\mathrm{A}$ and $\mathrm{B}$. The extract is said to be bacteriostatic if the ratio MBC: MIC is equal to 4 , whereas it is said to be bactericidal when it is equal to 2 .

\section{Results}

The Ethanol extract, which showed strong growth inhibition for bacteria $408 \mathrm{C} / 14,1541 \mathrm{C} / 14,485 \mathrm{C} / 14$ and $446 \mathrm{C} / 14$, exhibited a moderate trend for bacteria $1000 \mathrm{C} /$ 14 , and weak activity towards $499 \mathrm{C} / 14$. The potency of the extract was demonstrated at a minimum inhibition concentration value of $0.390 \mathrm{mg} / \mathrm{mL}$, by displaying a bacteriostatic effect for $446 \mathrm{C} / 14,408 \mathrm{C} / 14$, and a bactericidal activity against $1541 \mathrm{C} / 14$ and $485 \mathrm{C} / 14$. Activity was also observed for bacteria $499 \mathrm{C} / 14$ and $1000 \mathrm{C} / 14$ respectively at MIC 1.562 and $0.781 \mathrm{mg} / \mathrm{mL}$ (Table 1). Additionally, the Turkey Multiple Comparison showed significant variation $(P<0.05)$ of the crude extract efficacy within the range of $0.048 \mathrm{mg} / \mathrm{mL}$ to $12.5 \mathrm{mg} / \mathrm{mL}$. Another feature that confirmed this trend is the one-way analysis of variance which showed a pronounced means difference of the efficacy with an R squared value of 0.6326 .

Evaluation of the ethyl acetate extract showed growth inhibition of all MRSA tested with a MIC figure of

Table 1 Antibacterial activity of crude ethanol extract of Tieghemella heckelii on Methicillin-resistant and reference strains of Staphylococcus aureus

\begin{tabular}{lllll}
\hline Strains & MIC & MBC & MBC/MIC & Effect \\
\hline 408C/14 & $0,390 \pm 0.001$ & $1562 \pm 0.001$ & 4 & Bacteriostatic \\
1000C/14 & $0,781 \pm 0.001$ & $1562 \pm 0.001$ & 2 & Bactericidal \\
1541C/14 & $0,390 \pm 0.001$ & $0,781 \pm 0.001$ & 2 & Bactericidal \\
$485 C / 14$ & $0,390 \pm 0.001$ & $0,781 \pm 0.001$ & 2 & Bactericidal \\
$499 C / 14$ & $1562 \pm 0.001$ & $3125 \pm 0.001$ & 2 & Bactericidal \\
446C/14 & $0,390 \pm 0.001$ & $1562 \pm 0.001$ & 4 & Bacteriostatic \\
ATCCC 25923 & $0,781 \pm 0.001$ & $1562 \pm 0.001$ & 2 & Bactericidal \\
\hline
\end{tabular}

$M I C$ minimum inhibitory concentration, $M B C$ minimum bactericidal concentration, values are expressed as mean \pm SD of 3 experiments (ANOVA and Turkey test) 
$0.097 \mathrm{mg} / \mathrm{mL}$ for strains $408 / \mathrm{C}, 499 \mathrm{C} / 14,1000 \mathrm{C} / 14$ and $1541 \mathrm{C} / 14$. The plant extract has also demonstrated antibacterial activity towards strains $446 \mathrm{C} / 14$, and $485 \mathrm{C} / 14$ with MIC respective values of $0.195 \mathrm{mg} / \mathrm{mL}$ and $0.781 \mathrm{mg} / \mathrm{mL}$ (Table 2). Using the Turkey Multiple Comparison, the MIC means difference was significant for both strains $446 \mathrm{C} / 14$ and $485 \mathrm{C} / 14$. This was confirmed by the one-way analysis of variance with an $\mathrm{R}$ squared value of 0.6519 .

Methanol extract mixed with different MRSA inoculum strongly prevented the bacteria growth with MIC highest value of $0.048 \mathrm{mg} / \mathrm{mL}$ for bacterium $1000 \mathrm{C} / 14$ and $0.097 \mathrm{mg} / \mathrm{ml}$ for strains $408 \mathrm{C} / 14,485 \mathrm{C} / 14$, and $499 \mathrm{C} / 14$. For $1541 \mathrm{C} / 14$, the extract displayed moderate anti-MRSA potency at MIC value of $0.781 \mathrm{mg} / \mathrm{mL}$ with a bactericidal effect, and weak activity at $1.562 \mathrm{mg} / \mathrm{mL}$ for $446 \mathrm{C} / 14$ with a bacteriostatic effect (Table 3 ). The statistical analysis also showed significant variation of MIC means difference within the extract concentrations range of 0.048 to $12.5 \mathrm{mg} / \mathrm{mL}$ (Turkey Multiple Comparison test), which was confirmed by the one-way analysis of variance $\left(P=0.0003 ; \mathrm{R}^{2}=0.5987\right)$.

Residual Aqueous extract tested on MRSA in the screening experiment, revealed growth inhibition for strain $408 \mathrm{C} / 14$ with MIC value of $6.25 \mathrm{mg} / \mathrm{mL}$, activity against $1000 \mathrm{C} / 14$ with $\mathrm{MIC}$ value of $3.125 \mathrm{mg} / \mathrm{mL}$, and growth inhibition for bacteria strains $446 \mathrm{C} / 14,485 \mathrm{C} / 14$, $499 \mathrm{C} / 14$ and $1541 \mathrm{C} / 14$ with MIC value of $1.562 \mathrm{mg} / \mathrm{mL}$ (Table 4). Additionally, the extract displayed a bactericidal effect against all MRSA tested. Ultimately, the Turkey Multiple Comparison test showed significant variation of the extract efficacy within the concentrations range. This was confirmed by the one-way analysis of variance $\left(P=0.1323 ; \mathrm{R}^{2}=0.2013\right)$.

\section{Discussion}

The surveillance of multidrug resistance bacteria is a crucial challenge to the global health scientists. Therefore, the need to promote new natural compounds discovery is

Table 2 Antibacterial activity of ethyl acetate extract of Tieghemella heckelii on Methicillin- resistant and reference strains of Staphylococcus aureus

\begin{tabular}{lllll}
\hline Strain & MIC & MBC & MBC/MIC & Effect \\
\hline $408 C / 14$ & $0,097 \pm 0.003$ & $0,097 \pm 0.003$ & 1 & Bactericidal \\
1000C/14 & $0,097 \pm 0.003$ & $0,390 \pm 0.001$ & 4 & Bacteriostatic \\
$1541 C / 14$ & $0,097 \pm 0.003$ & $0,195 \pm 0.005$ & 2 & Bactericidal \\
$485 C / 14$ & $0,781 \pm 0.001$ & $1.562 \pm 0.001$ & 2 & Bactericidal \\
$499 C / 14$ & $0,390 \pm 0.001$ & $0,390 \pm 0.001$ & 1 & Bactericidal \\
$446 C / 14$ & $0,195 \pm 0.005$ & $0,390 \pm 0.001$ & 2 & Bactericidal \\
ATCC 25923 & $0,097 \pm 0.003$ & $0,195 \pm 0.005$ & 2 & Bactericidal \\
\hline
\end{tabular}

MIC minimum inhibitory concentration, $M B C$ minimum bactericidal concentration, values are expressed as mean \pm SD of 3 experiments (ANOVA and Turkey test)
Table 3 Antibacterial activity of methanol extract of Tieghemella heckelii on Methicillin- resistant and reference strains of Staphylococcus aureus

\begin{tabular}{lllll}
\hline Strain & MIC & MBC & MBC/MIC & Effect \\
\hline 408C/14 & $0,097 \pm 0.003$ & $0,195 \pm 0.005$ & 2 & Bactericidal \\
1000C/14 & $0,045 \pm 0.001$ & $0,195 \pm 0.005$ & 4 & Bacteriostatic \\
$1541 C / 14$ & $0,781 \pm 0.001$ & $1562 \pm 0.001$ & 2 & Bactericidal \\
$485 C / 14$ & $0,097 \pm 0.003$ & $0,195 \pm 0.005$ & 2 & Bactericidal \\
$499 C / 14$ & $0,097 \pm 0.003$ & $0,097 \pm 0.003$ & 1 & Bactericidal \\
$446 C / 14$ & $1562 \pm 0.001$ & $6,25 \pm 0.001$ & 4 & Bacteriostatic \\
ATCC 25923 & $0,045 \pm 0.001$ & $0,097 \pm 0.003$ & 2 & Bactericidal \\
\hline
\end{tabular}

MIC minimum inhibitory concentration, $M B C$ : minimum bactericidal concentration, values are expressed as mean \pm SD of 3experiments (ANOVA and Turkey test)

to be met for the preservation of humanity. From this perspective, traditional medicine appears to be the way out and as a result, it is practiced worldwide by use of herbal plants for therapeutic purposes [10]. To illustrate, in the West African region, especially in Côte d'Ivoire, people use plants as medications in rural settings $[11,12]$. Thus, Tieghemella heckelii is locally used for its anti-infectious properties [11]. However, the efficacy of the plant against multiresistant bacteria has not been investigated. Additionally, relatively less expensive antibacterial need to be developed in order to address patients subjected to infectious diseases, regardless of their living standards with the vision to completely eradicate the antibacterial drugs resistance. Early studies reported traditional medicinal plants to exhibit successful activity against methicillin-resistant Staphylococcus aureus, a gram-positive bacterium with an outer cell wall permeable to lipophilic solutes [13]. The results of the present study showed that the stem bark of Tieghemella heckelii had a great potential value against MRSA. Also, the MIC that ranged from $0.045 \mathrm{mg} / \mathrm{mL}$ to $12.5 \mu \mathrm{g} / \mathrm{mL}$ withstood this propriety of the plant part. However, the cutoff point was fixed at a MIC value of $0.097 \mathrm{mg} / \mathrm{mL}$. As a result, all other extract exhibiting figures above

Table 4 Antibacterial activity of aqueous extract of Tieghemella heckelii on Methicillin- resistant and reference strains of Staphylococcus aureus

\begin{tabular}{lllll}
\hline Strains & MIC & MBC & MBC/MIC & Effect \\
\hline $408 C / 14$ & $6,25 \pm 0.001$ & $12,5 \pm 0.001$ & 2 & Bactericidal \\
1000C/14 & $3125 \pm 0.005$ & $6,25 \pm 0.001$ & 2 & Bactericidal \\
$1541 C / 14$ & $1562 \pm 0.001$ & $3125 \pm 0.005$ & 2 & Bactericidal \\
$485 C / 14$ & $1562 \pm 0.001$ & $3125 \pm 0.005$ & 2 & Bactericidal \\
$499 C / 14$ & $1562 \pm 0.001$ & $3125 \pm 0.005$ & 2 & Bactericidal \\
$446 C / 14$ & $1562 \pm 0.001$ & $3125 \pm 0.005$ & 2 & Bactericidal \\
ATCC 25923 & $3125 \pm 0.005$ & $6,25 \pm 0.001$ & 2 & Bactericidal \\
\hline
\end{tabular}

$M I C$ minimum inhibitory concentration, $M B C$ minimum bactericidal concentration, values are expressed as mean \pm SD of 3 experiments (ANOVA and Turkey test) 
the MIC aforementioned against the bacteria strains was not considered. To illustrate, from the prospective four active extracts, both the ethyl acetate and methanolic extracts displayed highly strong antibacterial activity because they exhibited MIC lowest values of $97 \mu \mathrm{g} / \mathrm{mL}$ and $45 \mu \mathrm{g} / \mathrm{mL}$. But, methanol extract appears to contain the most promising antibacterial agent (MIC $45 \mu \mathrm{g} / \mathrm{mL}$ ). Additionally, plant extracts showed inhibition concentrations lower than that reported elsewhere. In comparison with earlier antibacterial activity investigation, the extracts of the stem bark of Tieghemella heckelii showed stronger efficacy against MRSA than the grap-seed extract which exhibited MIC values of $1000 \mu \mathrm{g} / \mathrm{mL}$ to $5000 \mu \mathrm{g} / \mathrm{mL}$ [14]. When compared with studies carried out with Piper betle to assess the antibacterial activity, the present evaluation of plant extracts' efficacy against MRSA showed lower MIC values compared to 78 to $156 \mu \mathrm{g} / \mathrm{mL}$ exhibited by the leaf extracts of Piper betle against gram positive Staphylococcus aureus [13].

\section{Conclusion}

The screening experiment conducted with the MIC and MBC determination, showed that the stem bark of Tieghemella heckelii contains ingredients that prevent the growth of the tested micro-organisms (6 Methicillinresistant Staphylococcus aureus). Therefore, they displayed high antimicrobial properties towards the gram-positive bacteria tested. Additionally, the lower MIC values of 0.048 and $0.097 \mathrm{mg} / \mathrm{mL}$ (Methanol and Ethyl Acetate extracts) were respectively recorded on $16.7 \%$ and $83.3 \%$ of the investigated MRSA species whereas the lower MBC values of 0.097 and $0.195 \mathrm{mg} / \mathrm{mL}$ (Ethyl acetate and Methanol extracts) exerted a credible activity on $33.3 \%$ and $50.0 \%$ of the MRSA. These encouraging results from the Methanol and Ethyl Acetate extracts, brought about the perspective of further molecular purification. Moreover, the lower $\mathrm{MBC}$ values of the plant extract raised the toxicity concern and further study was carried out on human cell lines to address this issue.

Consequently, the present study, which revealed the antibacterial properties of the plant extracts, is a justification of the use of Tieghemella heckelii's stem bark to treat some of the tropical infectious diseases in Africa and particularly in Côte d'Ivoire. This fact is withstood by the bactericidal effect of the Residual Aqueous Extract mostly used in traditional medicine. Nevertheless, there is still room for an in depth investigation, in order to make the plant best useful to rural settings and to select it as an alternative to bacteria resistance.

\section{Abbreviation}

ATCC: American Type Collection Culture; DMSO: Dimethyl Sulfoxide; ESBL: Extended-Spectrum Beta-Lactamase; GSE: Grasp-seed extract;
MBC: Minimum bactericidal concentration; MIC: Minimum inhibitory concentration; MRSA: Methicillin-resistant Staphylococcus aureus.;

SD: Standard deviation

\section{Acknowledgements}

The authors of this manuscript are grateful to Institut Pasteur de Côte d'Ivoire, which provided necessary laboratory equipment.

\section{Funding}

Not Applicable.

\section{Availability of data and materials}

Institut Pasteur Côte d'Ivoire/Université Nangui Abrogoua/Centre Suisse de Recherches Scientifiques Côte d'Ivoire.

\section{Authors' contributions}

BGK conceived, designed, carried out the extraction experiments, performed the bioassays, conducted the statistical analysis and wrote the draft of the manuscript. NKG designed the bioassays, validated the results of the experiments and participated in the drafted manuscript. MWK participated in the experiments' design and results validation, in the drafted manuscript and statistical analysis. VG participated in bioassays design and results interpretation. Additionally, VG received the patients who consented for routine sample collection and diagnosis. JKC contributed in plant extracts preparation and fractionation. MD designed the bioassays, validated the results of the experiments and participated in the drafted manuscript. All authors read and approved the final manuscript.

\section{Competing interests}

The authors declare that they have no competing interests.

\section{Consent for publication}

The authors consented to publish the present work.

Ethics approval and consent to participate

Not applicable.

\section{Publisher's Note}

Springer Nature remains neutral with regard to jurisdictional claims in published maps and institutional affiliations.

\section{Author details}

${ }^{1}$ Institut Pasteur Côte d'Ivoire, Département de Bactériologie/Virologie, Centre National de Reference Antibiotiques, 3 Avenue de I'Université Cocody, B.P 490, Abidjan 01, Côte d'Ivoire. ²Université Nangui Abrogoua Côte d'Ivoire, B.P 801, Abidjan 01, Côte d'Ivoire. ${ }^{3}$ Centre Suisse de Recherches Scientifiques en Côte d'Ivoire, Km 17, Dabou, Côte d'Ivoire.

Received: 10 December 2015 Accepted: 15 March 2017

Published online: 27 March 2017

\section{References}

1. Nauciel C. Bactériologie médicale. Masson (Ed), Paris 2000.

2. Rapport CNR. Institut Pasteur Côte d'Ivoire, Abidjan, Côte d'Ivoire2014

3. Guessennd N, Gbonon VC, Tiecoura KB, Kacou-N'douba A, Ouattara DN, Boni-Cissé C, Dosso M, et le GER-BMR. Evolution de la résistance bactérienne a l'imipenème en Côte d'Ivoire de 2005 à 2009. Abidjan, Côte d'Ivoire: Colloque scientifique de l'Institut Pasteur de Côte d'Ivoire: pathologies émergentes et biologie intégrative; 2009.

4. Salem MZM, Salem AZM, Camacho L, Ali HM. Antimicrobial activities and phytochemical composition of extracts of Ficus species: An overview. J Microbiol Res. 2013;7:4207-19.

5. Diallo AM. Etude des plantes médicinales de mafunke (région de Tombouctou), Phytochimie et Pharmacologie de Maerua crassifolia Forsk (Capparidacee), Thèse. Mali: Université de Bamako; 2005.

6. Kipre BG, Coffi AA, Adima AA, Gokou T, Ito Y, Gosse BK. Total Chemical Analysis of the seed of Tieghemella heckelii by diverse chromatography techniques. J Liq Chromatogr Relat Technol. 2008:31:250-62.

7. Koné WM, Kamanzi AK, Terreaux C, Hostettmann K, Traoré D, Dosso M. Traditional medicine in North Cote d'lvoire, screening of 50 medicinal plants for antibacterial activity. J Ethnopharmacol. 2004;93:43-9. 
8. Fauchere I-L, Avril J-L. Bactériologie générale et médicale. Paris: Edition Ellipses; 2002.

9. National Committee for Clinical laboratory standards, 2002: Performance standards for antimicrobial susceptibility testing; 12th informational supplement

10. Khan R, Islam B, Akram M, Shakil S, Ahmad A, Manazir SA, Mashiatullah S, Khan AU. Antimicrobial Activity of Five Herbal Extracts against Multi Drug Resistant (MDR) Strains of Bacteria and Fungus of Clinical origin. Molecules. 2009;14:586-97.

11. Bouquet A, Debray M. Travaux et Documents de I'O.R.S.T.O.M, Plantes Médicinales de la Côte d'lvoire; 1974. p. 11-175.

12. World Health Organization (WHO), Ministerial Conference Antibiotic Resistance. Joining forces for future health, The Hague-Netherlands 2014 .

13. Demetrio Jr LV, Andrade IJ, Puzon MJJ, Cabrera CE, Rivera WL. Antibacterial activities of ethanol extracts of Phillipine medicinal plants against multidrug-resistant bacteria. Asian Pac J Trop Biomed. 2015:5(7):532-40.

14. Su X, Howell AB, D'Souza DH. Antibacterial effects on plant-derived extracts on methicillin-resistant Staphylococcus aureus. Food Borne Pathoq Dis. 2012;9(6):573-8

Submit your next manuscript to BioMed Central and we will help you at every step:

- We accept pre-submission inquiries

- Our selector tool helps you to find the most relevant journal

- We provide round the clock customer support

- Convenient online submission

- Thorough peer review

- Inclusion in PubMed and all major indexing services

- Maximum visibility for your research

Submit your manuscript at www.biomedcentral.com/submit
Biomed Central 